\title{
Community Colleges and Networking in New Jersey
}

\author{
John M. Cohn, Director \\ Sherman II. Masten Learning Resource Center \\ County College of Morris, New Jersey
}

As a general rule, one must be cautious about heralding the advent of change. In New Jersey, however, there are signs that the foundations of a new environment for library network development are being established. As this new environment takes shape, there seems little doubt that it will have important implications for the state's community college libraries.

In New Jersey community colleges fall under the general jurisdiction of the State Board of Higher Education but remain relatively autononous institutions established and primarily financed through county governments. The County College Act of 1962 authorized one or more contiguous counties to establish a county college; to date. fifteen counties have established colleges under this legislation. In all, 18 institutions in the state offer an AA or AS degree, with one Community College Commission contracting the services of other postsecondary institutions to offer programs of instruction similar to those offered at a county college.

At present, the major instrument for cooperation among New Jersey's libraries on a statewide basis is the New Jersey Library Network, which is designed to facilitate interlibrary loan and is meant to include all of the state's libraries. But the structure of this network does not effectively address the needs of academic libraries nor does it attempt to utilize their potential. Encouraging a pattern of vertical interaction, the network centers on the designation of certain larger public libraries as area libraries which perform a variety of services for local public libraries. The latter constitute the first level of service in the state, while the area libraries are the second level, and the New Jersey State Library, Princeton University, Rutgers University, and the Newark Public Library are a third level of regional research library services.

In effect, this arrangement does not promote broad participation among different types of libraries in a networking process-something acknowledged by the State Library itself as well as in a report issued recently by a County and Municipal Government Study Commission. However, it now seems likely that a new multitype networking environment is emerging in the state. Sparked by new leadership at the State Library and perhaps to be fueled by additional enabling legislation as well as by new funding patterns (though not necessarily more money), an alternative structure will attempt to provide support for regional library cooperatives which would include all types of libraries in horizontal relationships designed to encourage resource sharing, cooperative acquisitions, regional reference and referral services, the shared use of new technology, and so forth

For community college libraries, this new environment will be considerable significance although to some extent it will reflect patterns already in existence in the state. Many community college libraries have already forged ties with area and other non-academic libraries, and reciprocal borrowing, joint service, and other such agreements among contiguous libraries are fairly widespread. At least one county has preliminary plans for an Information Resource Consortium to embrace the county college, the county library, and a vocational-technical school. In Morris County an online circulation system will link the county college, the county library and, in time. smaller public libraries.

\section{Back Order Problems?}

We are tenacious at Book House. In our concern about your order, we continue to birddog it until we deliver the book or find it out-ofprint. Only upon your instructions do we cancel. We call our program "Concerned Service" and it pays off for academic libraries throughout the U.S.A. Let us show you! For any book in print (U.S. and Canada), send your orders to the Book House.

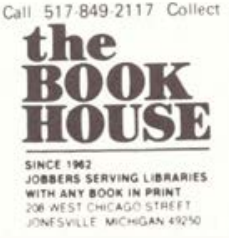


It is becoming apparent that an important factor in many of the new networking plans will be computerization, particularly the installation and sharing of online systems. Of interest to community college libraries here has been the formulation and (to date) partial implementation of a three-phased state-funded program involving New Jersey's eight state colleges and two other publicly supported academic institutions. Under this program each of the ten libraries has joined the OCLC network and will soon participate in a cooperative, vendor-supplied online circulation control system. There are also plans to explore the feasibility of a joint dead storage facility.

Given the autonomy of the community colleges and the absence of a central funding base, a similar package will be more difficult to put together for them. However, with strong indications of impending (and actual) state and county budget-cutting, community college libraries in New Jersey must be both energetic and imaginative in their search for alternative funding patterns to make possible the expansion of innovative service and the establishing of new, cooperative organizational arrangements.

\section{BETA PHI MU AWARD}

Since 1954 Beta Phi Mu, the national honorary library science society, and ALA has recognized library school faculty or anyone making a distinguished contribution to education for librarianship with the Beta Phi Mu Award. Nominations are now being accepted for this annual award of $\$ 500$ and a citation of achievement.

ACRL members are encouraged to nominate outstanding library educators for this award. The 1980 recipient of the Beta Phi Mu Award was Virginia Lacy Jones, dean of the School of Library and Information Studies, Atlanta University.

Nominations should be sent to the 1980-81 chair of the Beta Phi Mu Award jury, Patricia Reeling, Graduate School of Library and Information Science, 4 Huntington St, Rutgers University, New Brunswick, NJ 08903. The deadline for nomination is January 15, 1981. For more information and nomination forms, contact Ann Cunniff, ALA Awards Committee staff liaison, 50 E. Huron St., Chicago, IL 60611

Erratum-The gift of rare French literature to the University of Missouri at Kansas City was donated by Professor William L. Crain, not Crarin as reported in the September issue.

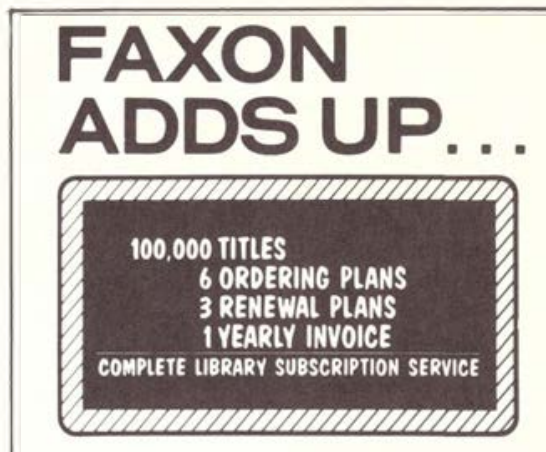

Faxon offers librarians a complete range of up-to-date computerized subscription services. Write or call Faxon today for our LIBRARIANS' GUIDE and SERVICE BROCHURE.

For total subscription service... Faxon adds up.

\section{EWAFE.W. Faxon Company, Inc.}

\author{
Library Magazine Subscription Agency \\ 15 Southwest Park. Westwood. Massachusetts 02090 \\ Tel: 800-225-6055 (toll-free) \\ 617.329.3350 (collect in Mass. and Canada only)
}

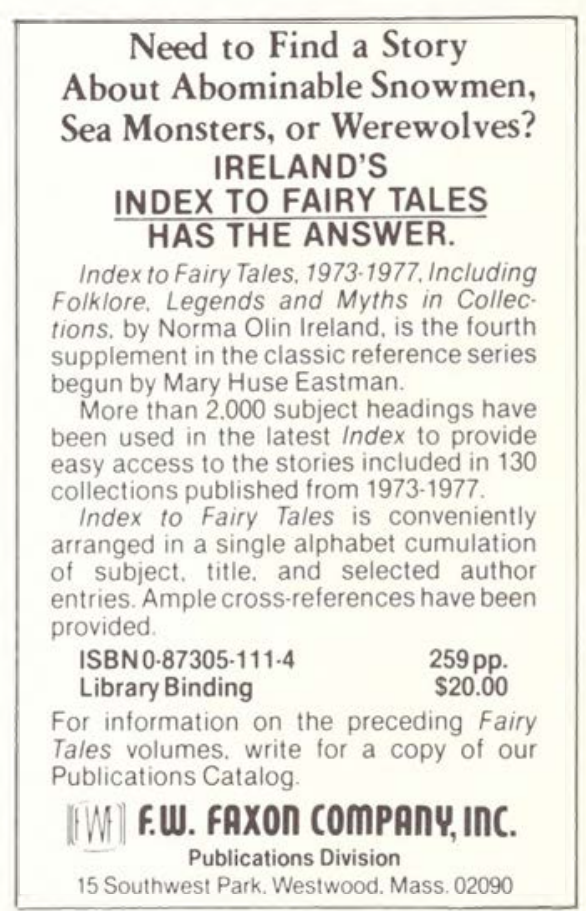

